
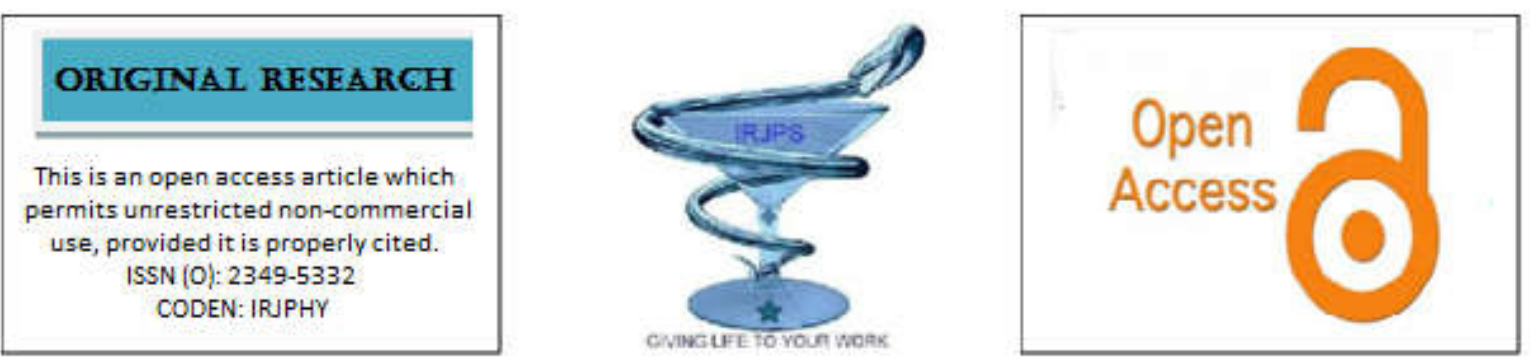

\title{
EVALUATION OF ANTI-ARTHRITIC ACTIVITY OF NIGELLA SATIVA SEEDS EXTRACT IN RATS
}

\author{
S. Amreen Sultana", G. N. S. S. Chandra Sekhar, J. Gopichand, P. Sharmila Nirojini, A. Narendra Babu
}

Department of Pharmacology, Chalapathi Institute of Pharmaceutical Sciences, Lam, Guntur.

\begin{abstract}
Background: The seeds and oil if Nigella sativa (Ranunculaceae) have long been used traditionally to treat inflammatory disorders like rheumatoid arthritis etc. Though, it has not yet been pharmacologically assessed for rheumatoid arthritis. Objective: The objective of the present study is to evaluate the anti-arthritic activity of ethanolic extract of Nigella sativa seeds (NSEE). Methods: Preliminary phytochemical analysis was carried out by using standard procedures. Anti-arthritic potential was evaluated in-vitro using protein denaturation method (egg albumin) at concentrations $25-800 \mu \mathrm{g} / \mathrm{ml}$ and in vivo via Complete Freund's Adjuvant induce arthritic model at 200 and $400 \mathrm{mg} / \mathrm{kg}$ doses. Results: The results revealed the presence of alkaloids, carbohydrates, flavonoids, phenols, terpenoids etc. The in-vitro results exhibited maximum \% inhibition of protein denaturaion at $800 \mu \mathrm{g} / \mathrm{ml}$ i.e. $75 \%$. The results of CFA model have shown that NSEE significantly $(\mathrm{P}<0.0001)$ prevents alterations in paw volume, joint diameter and body weight. It also ameliorates the changes in hematological, biochemical and histopathological parameters. Conclusion: The results support the traditional use of Nigella sativa seeds as potential anti-arthritic agent and can be used for the treatment of rheumatoid arthritis.
\end{abstract}

Keywords: Nigella sativa, Rheumatoid arthritis, Protein denaturation, Complete Freund's Adjuvant

Corresponding Author: S. Amreen Sultana Email: amreensultana5185@gmail.com
Indian Research Journal of Pharmacy and Science; 24(2020)2044-2056; Journal Home Page: https://www.irjps.in DOI: $10.21276 /$ irjps.2020.7.1.3 


\section{INTRODUCTION}

Rheumatoid arthritis (RA) is an autoimmune disease in which the body's immune system which normally protects its health by attacking foreign substances like bacteria and viruses mistakenly attacks the joints. This creates inflammation that causes the tissue that lines the inside of joints (the synovium) to thicken, resulting in swelling and pain in and around the joints. The synovium makes a fluid that lubricates joints and helps them move smoothly. If inflammation goes unchecked, it can damage cartilage, the elastic tissue that covers the ends of bones in a joint, as well as the bones themselves.
Over time, there is loss of cartilage, and the joint spacing between bones can become smaller. Joints can become loose, unstable, painful and lose their mobility. Joint deformity also can occur. Joint damage cannot be reversed, and because it can occur early, doctors recommend early diagnosis and aggressive treatment to control RA. Rheumatoid arthritis most commonly affects the joints of the hands, feet, wrists, elbows, knees and ankles. The joint effect is usually symmetrical. That means if one knee or hand if affected, usually the other one is, too. Because RA also can affect body systems, such as the cardiovascular or respiratory systems, it is called a systemic disease. Systemic means "entire body" ${ }^{1}$.
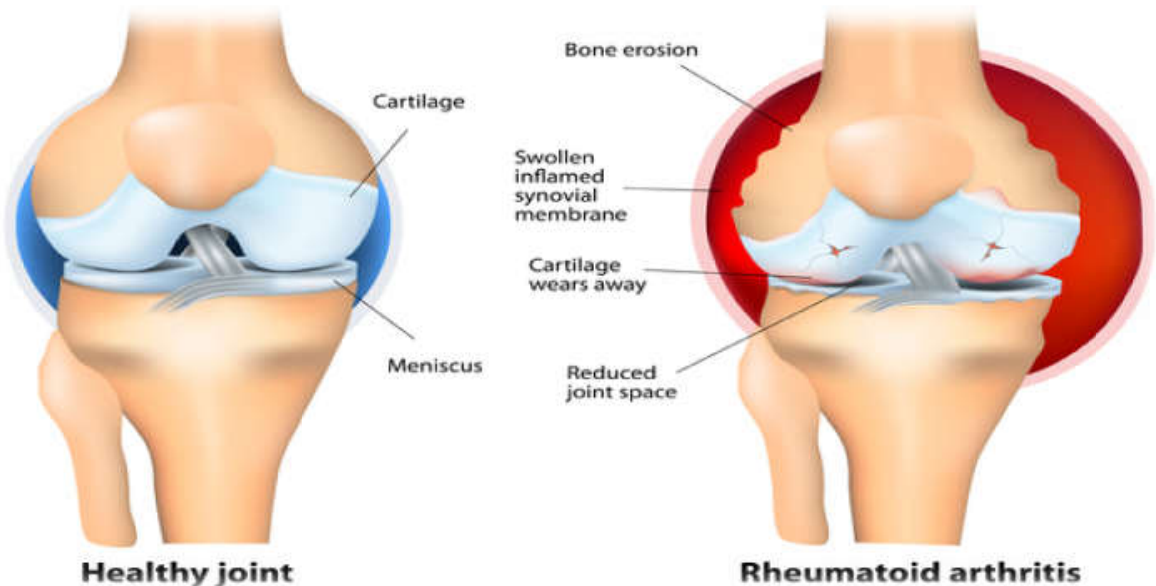

Fig 1: Rheumatoid Bone

In the plant kingdom there is a remedy for every disease. The use of plants as medicine dates from the earliest years of man's evolution. Today, $75 \%$ of the world's population still relies on those plants and other tools of traditional medicine as they are unable to have access and/or afford allopathic medicines. In the traditional system, various indigenous plants are being used in the diagnosis, prevention and elimination of physical, mental or social imbalance. Recently, the usage of phytomedicine has been amplified dramatically for numerous ailments because of not only their easy accessibility and low cost but also the belief that natural remedies have fewer harmful effects as compared to synthetic medicines. The development of new products from natural sources is also encouraged because it is estimated that, of the 300,000 herbal species that exist globally, only $15 \%$ have been explored for their pharmacological potential. Among several medicinal plants, Nigella sativa $\mathrm{L}$. (Ranunculaceae) has been considered one of the most treasured nutrient-rich herbs in history around the world $^{2,3,4}$.

Nigella sativa Linn., also called as black cumin and kalonji is an annual herbaceous plant belonging to the family Ranunculaceae. Nigella is an important seed spice has origin from Mediterranean region of Asia to North India. Nigella is widely cultivated throughout South Europe, Syria, Egypt, Saudi Arabia, Iran, Pakistan, India and Turkey. In India it is cultivated commercially in West Bengal, Punjab, Jharkhand, Himachal Pradesh, Bihar and Assam. In Islamic medicine, the use of the black seeds is recommended in daily use because it is regarded as one of the greatest forms of healing medicine available. Prophet Muhammad (PBUH) once stated that the black seed can heal every disease-except death-as narrated in the following hadith "Hold onto the use of the black seeds for in it is healing for all diseases except death"(Sahih Bukhari vol. 7 book 71 \# 592). Thus, the glorified status of NS among the Muslim 
community is as Habbat Albarakah, with the term "Albarakah" signifying its "blessed" status. N. sativa seeds, as nutritional and medicinal plant, have traditionally been used for thousands of years as folk medicine and some of its active compounds were reported against many ailments. Known to be as one of the prophetic medicines and the emerging demands in utilizing natural products to replace the synthetic drugs, $N$. sativa has become amongst the top candidates selected by researchers as a natural product in medical field ${ }^{5,6}$.

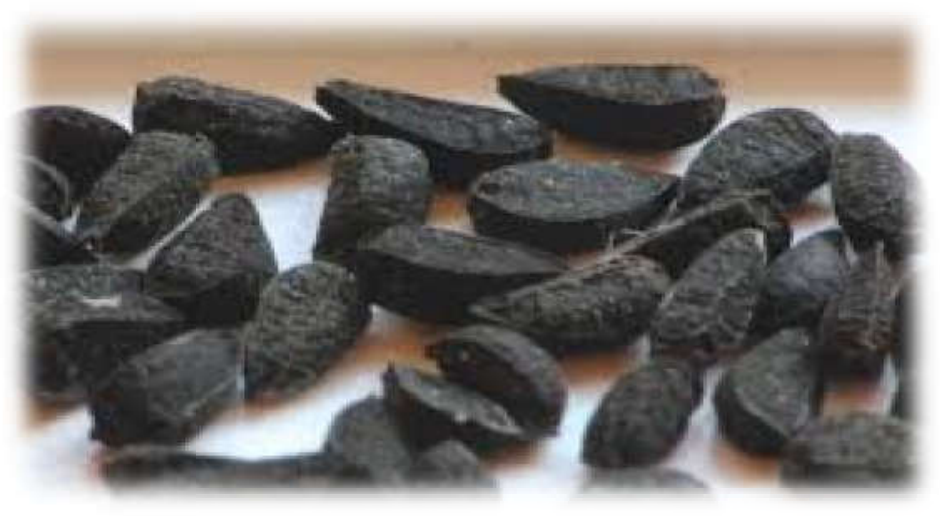

Fig 2: Nigella sativa seeds

$N$. sativa seeds are used in Palestine to treat dizziness and high blood pressure. The seed oil is used against lung diseases and arthritis, while black seed oil soap is used for improving skin glossiness and for blood circulation stimulation. Aqueous extracts of black seed are taken orally for the treatment of high blood pressure, heart disease and sexual weakness ${ }^{7}$.

$\begin{array}{lll}\text { Taxonomical Classification } & \\ \text { Kingdom } & : & \text { Plantae } \\ \text { Subkingdom } & : & \text { Tracheobionta } \\ \text { Superdivision } & : & \text { Spermatophyta } \\ \text { Division } & : & \text { Magnoliophyta } \\ \text { Class } & : & \text { Magnoliopsida } \\ \text { Subclass } & : & \text { Magnoliidae } \\ \text { Order } & : & \text { Raunculales } \\ \text { Family } & : & \text { Ranunculacea } \\ \text { Genus } & : & \text { Nigella } \\ \text { Species } & : & \text { sativa }\end{array}$

Bionomial name $\quad$ : $\quad$ Nigella sativa. L

\section{Botanical Description}

Synonyms: Nigella indica Roxb. ex Flem., Nigella Truncate Viv.

Common Names ${ }^{9}$ : Black cumin, Fennel flower, Roman coriander, Nutmeg flower, Black seed, Black caraway, Damascena, Devil in - the- bush, Wild onion seed, Kalonji, Kalojeera.

\section{MATERIALS AND METHODS}

\section{Procurement of Plant Material}

For the present investigation, seeds of Nigella sativa were purchased from the local market in Guntur, Andhra Pradesh. The seeds were identified and authenticated by a botanist in Acharya Nagarjuna University and the specimen sample is deposited in the Pharmacognosy division, Chalapathi Institute of Pharmaceutical Sciences.

\section{Drying and Size Reduction}

The seeds were carefully shade dried at room temperature and then seeds were subjected to size reduction to make powder by using electric grinder. The ground mass was first defatted with petroleum ether $\left(40-60^{\circ} \mathrm{C}\right)$ using the Soxhlet apparatus. Then, 
the powder was macerated in $800 \mathrm{ml}$ ethanol $(80 \%$, v/v) for 72 hours, and the mixture was subsequently filtered and concentrated in vacuo at $40^{\circ} \mathrm{C}$. The extract obtained was used for evaluation of phytochemicals and pharmacological activities.

\section{ANTI-ARTHRITIC ACTIVITY}

\section{In-vitro Activity}

Evaluation of anti-arthritic effect of Nigella sativa on inhibition of protein denaturation using egg albumin $^{10}$

The reaction mixture $(5 \mathrm{ml})$ included egg albumin (0.2 ml), phosphate buffered saline $2.8 \mathrm{ml}(\mathrm{pH} 6.4)$ and $2 \mathrm{ml}$ of Nigella sativa seed extract and diclofenac sodium at various concentrations $(12.5,25,50,100$, 200,400 and $800 \mu \mathrm{g} / \mathrm{ml}$ ), respectively. Equal volume of double-distilled water served as control. The mixtures were incubated at $37 \pm 2{ }^{\circ} \mathrm{C}$ in a Biochemical oxygen demand (BOD) incubator for 15 min and then heated at $70{ }^{\circ} \mathrm{C}$ for $5 \mathrm{~min}$. Their absorbance was measured at $660 \mathrm{~nm}$. The percentage inhibition of protein denaturation was appraised using under mentioned formula:

$$
\begin{gathered}
\% \text { inhibition }=(\text { Abs control }- \text { Abs test sample } / \text { Abs } \\
\text { control }) * 100
\end{gathered}
$$

Abs $=$ Absorbance.

\section{In-vivo Activity}

Evaluation of anti-arthritic activity of Nigella sativa against complete freund's adjuvant (CFA) induced arthritis in rats

\section{a) Animals}

Healthy adult male wistar rats weighing 250-300 gm were selected for the study. The animals were acclimatized to standard laboratory condition with temperature $25 \pm 2{ }^{\circ} \mathrm{C}$ and fed with standard animal pellet feed (Hindustan lever limited) and water ad libitum. The protocol was approved (Approval: 01/IAEC/CLPT/2018-19) by Institutional by Animal Ethics Committee (Reg no: 1048/a/07/CPCSEA) constituted for the purpose of animal experimentation as per CPCSEA guidelines.

\section{b) Preparation of dose for extracts}

Ethanolic extract $(200 \mathrm{mg} / \mathrm{kg} \& 400 \mathrm{mg} / \mathrm{kg})$ of Nigella sativa seed was formulated as suspension using 2\% Tween-80 as solvent. The strength of the suspension was according to the dose administered and was expressed as weight of dried extract.

c) Material and Methods

i. Chemicals: Incomplete freund's adjuvant (IFA), Complete freund's adjuvant (CFA), Dexamethasone (DEX), 2\% tween 80, Nigella sativa ethanolic extract (NSEE)

ii. Treatment Design ${ }^{11}$ :

Group I: Normal control / Vehicle control (2\% tween-80, p.o.)

Group II: Non-arthritic control / IFA treated group ( $2 \%$ Tween 80 , p.o.)

Group III: Arthritic control / CFA treated group (subplantar injection of $0.1 \mathrm{ml}$ of CFA)

Group IV: Positive control (DEX 3.0 $\mathrm{mg} / \mathrm{kg}$, i.p.)

Group V: Test-I (NSEE $200 \mathrm{mg} / \mathrm{kg}$, p.o.)

Group VI: Test-II (NSEE $400 \mathrm{mg} / \mathrm{kg}$, p.o.)

The rats were assigned to 6 groups $(n=5)$ and injected with a $0.1 \mathrm{ml}$ suspension of CFA $(5 \mathrm{mg} / \mathrm{ml}$ of heatkilled $M$. tuberculosis in paraffin oil) into the left hind paw except the animals in normal control. Arthritic control group received only subplantar injection of complete freund's adjuvant (CFA), while non-arthritic control/incomplete freund's adjuvant (IFA) group received only subplantar injection of 0.1 ml IFA (sterile paraffin oil). The animals in normal and non-arthritic control group received 2\% tween80 while the animals in Test-I \& Test-II received NSEE (200 and $400 \mathrm{mg} / \mathrm{kg}$, p.o., respectively) every day after establishment of arthritis, i.e., from day 9 to day 21. DEX was administered to rats in positive control every alternate day after establishment of arthritis, i.e., from day 9 to day 21 .

\section{PARAMETERS ${ }^{12,13}$}

\section{Paw Volume}

The paw volume was measured using a water displacement plethysmometer. This was done before subplantar injection of CFA (day 0) and every other 
day for 21 days after subplantar injection of CFA and IFA. Data obtained for paw volumes was recorded as percentage increase in paw volume from day 0 . The $\%$ increase in paw volume is calculated as per the formula below:

$$
\% \text { Increase in paw volume }=\left(\mathrm{T}_{0}-\mathrm{T}_{\mathrm{t}} / \mathrm{T}_{0}\right) * 100
$$

Where $T_{0}$ is the mean of paw thickness at day 0 and $T_{t}$ is the mean of paw thickness at a particular time.

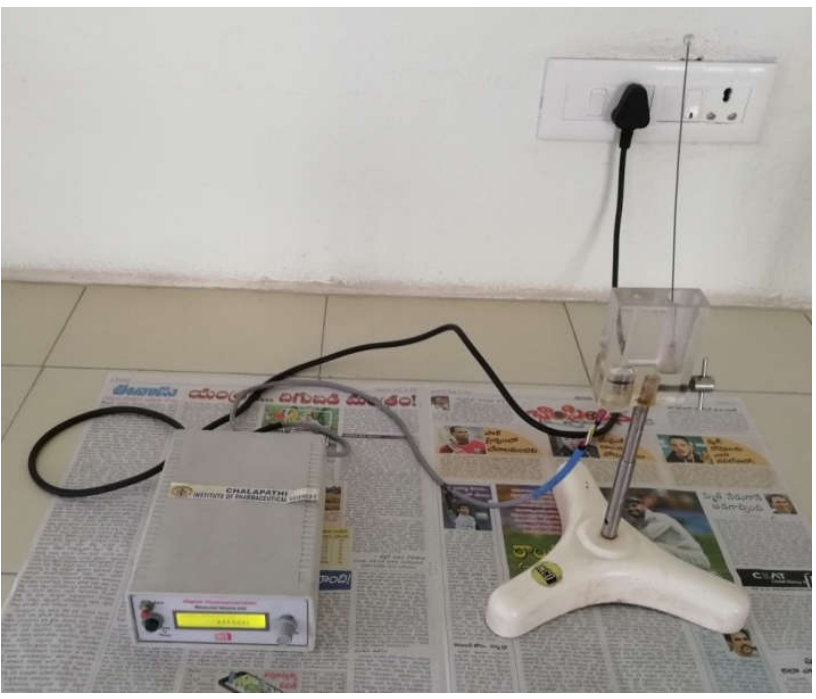

Fig 3: Digital Plethysmometer

\section{Joint Diameter}

The joint diameter was measured using a Vernier caliper. This was done before subplantar injection of CFA (day 0) and every other day for 21 days after subplantar injection of CFA and IFA. The data obtained was recorded as $\%$ change in joint diameter.
$\%$ change in joint diameter change $=\left(\mathrm{J}_{\mathrm{t}}-\mathrm{J}_{0} / \mathrm{J}_{\mathrm{t}}\right) *$ 100

Where $J_{t}$ is the weight of animal at time $t$ and $J_{o}$ is the weight of animal on day 0 .

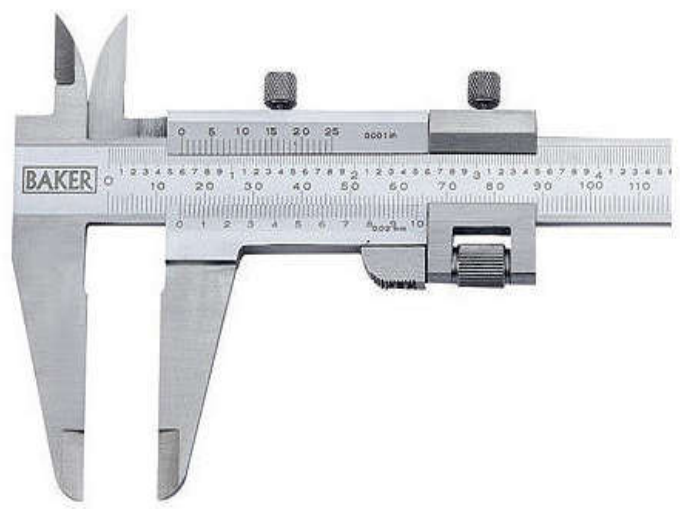

Fig 4: Vernier Caliper 


\section{Body Weight}

Animal's body weight for all groups was monitored starting from day 0 and repeated every other day for 21 days after subplantar injection of CFA and IFA. The percent change in body weight was calculated using the following formula:

\% change in weight $=\left(\mathrm{W}_{\mathrm{t}}-\mathrm{W}_{0} / \mathrm{W}_{\mathrm{t}}\right) * 100$

Where $W_{t}$ is the weight of animal at time $t$ and $W_{o}$ is the weight of animal on day 0 .

\section{Arthritic Index}

Development and severity of induced arthritis were evaluated by a visual scoring system of the clinical signs and symptoms on scale of $0-4$ per limb. A score of the both hind limb was counted and a score more than 1 exhibits the arthritis whereas a maximum score of the arthritis is 8 . The measurement was done on day 9 post CFA injection and repeated on day $12,15,18,21$.

Table 1: Description and scoring of arthritis in rats

\begin{tabular}{|c|c|}
\hline Description & Score \\
\hline No swelling or erythema & 0 \\
\hline Slight swelling and/or erythema of the limb & 1 \\
\hline Mild swelling and/or erythema of the limb & 2 \\
\hline Gross swelling and erythema of the limb with limited joint use & 3 \\
\hline Gross deformity and inability of the limb with joint rigidity & 4 \\
\hline
\end{tabular}

\section{Blood Analysis}

On day 21, blood was collected under ether anesthesia via cardiac puncture and was collected in 2 tubes, one with anticoagulant and the other without anticoagulant.

\section{- Biochemical Parameters}

The blood without anticoagulant was centrifuged for $5 \min (4900 \mathrm{rpm})$ and the serum was collected. The serum samples obtained were used for the analysis of biochemical parameters like ALP, AST, ALT, Rheumatoid factor (RF) and Creactive protein (CRP) using standard kits in the fully automatic biochemical analyzer.
- Hematological Parameters

Hematological parameters like hemoglobin content $(\mathrm{Hb})$, total leukocyte (WBC) and erythrocytes (RBC) count, erythrocyte sedimentation rate (ESR), and platelets (PLT) were determined in blood with anticoagulant by the usual standardized laboratory method.

\section{Histopathology}

The animals were sacrificed on day 22 by cervical dislocation. Ankle joints were separated from the hind paw, weighed and immersed in $10 \%$ buffered formalin for $24 \mathrm{~h}$ followed by decalcification in 5\% formic acid, processed for paraffin embedding sectioned at $5 \mu \mathrm{m}$ thickness. The sections were 
stained with haematoxylin and eosin and evaluated under light microscope for the presence of large joint space, cells infiltration, vascularization and bone erosion. The slides are also evaluated for their synovial architecture.

RESULTS AND DISCUSSION

In-vitro Anti-Arthritic Activity
Nigella sativa at several doses $(25-800 \mu \mathrm{g} / \mathrm{ml})$ provided considerable protection against denaturation of egg albumin. The results showed that extract produced $75.85 \%$ inhibition of protein denaturation at $800 \mu \mathrm{g} / \mathrm{ml}$ while diclofenac sodium brought about $82.77 \%$ suppression of protein denaturation at $800 \mu \mathrm{g} / \mathrm{ml}$ (Fig 5).

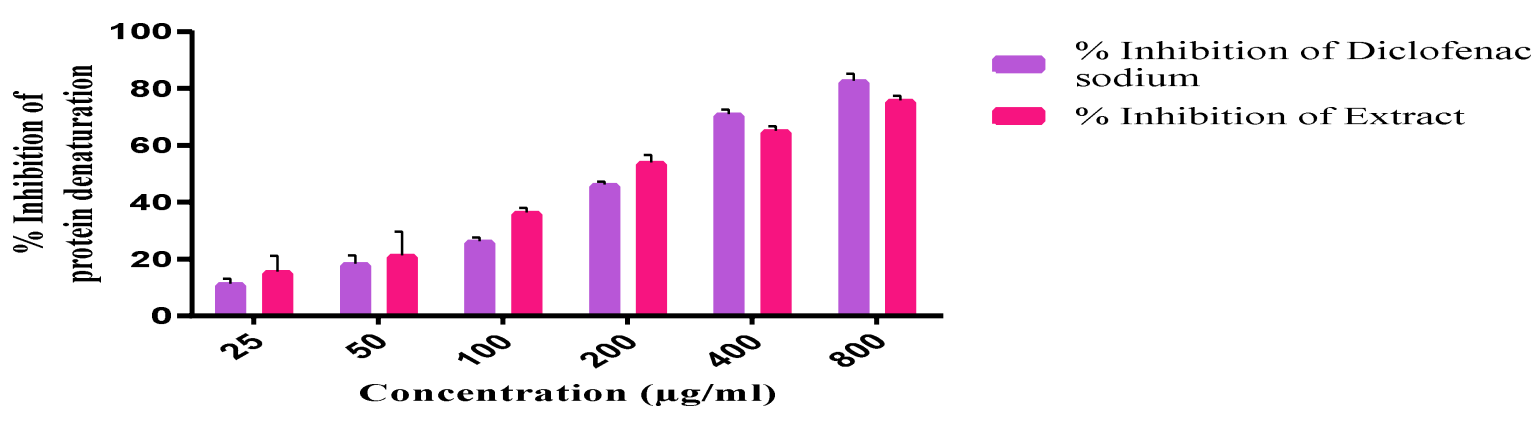

Fig 5: Effect of NESS on protein denaturation using fresh hen's egg albumin

\section{In-vivo Anti-Arthritic Activity}

Complete Freund's adjuvant (CFA) $(0.1 \mathrm{ml}$, subplantar) was used to produce arthritis in animals which induces significant inflammatory response characterized by paw and joint swelling in rats. The response was biphasic, consisting of acute and polyarthritis phase. The acute manifestation of disease was corresponding to $0-8$ days characterized by inflammation of ipsilateral paw, followed by polyarthritis phase corresponding to 9-21 days, characterized by involvement of contralateral paw. Dexamethasone ( $3 \mathrm{mg} / \mathrm{kg}$, ip.) showed significant protection against CFA by preventing redness, swelling and bone destruction. The tests, I \& II showed similar results but Test I exhibited significant protection against CFA.

Paw Volume: The volume of the ipsilateral (primary lesions) as well as contralateral (secondary lesions) paws in the CFA rats increased progressively. However, there was no significant change in contralateral paw volume. After the 12th day progressive increase in paw volume was seen in all CFA administered groups. The rats receiving DEX (3 $\mathrm{mg} / \mathrm{kg}$, ip.) or extracts (NSEE 200 and $400 \mathrm{mg} / \mathrm{kg}$ ) significantly decreased the paw volume from day 10 when compared to arthritic control (Fig 6). Normal animals kept under experiment did not show paw swelling.

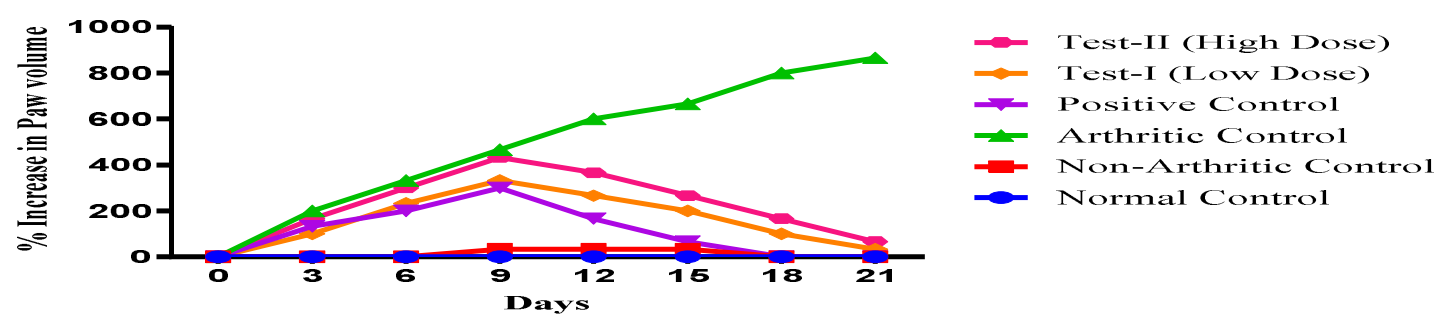

Fig 6: Effect of NESS on \% change in paw volume in CFA induced arthritic rats

Joint Diameter: Ankle joint diameter of rats significantly increased in all rats which were treated with CFA. NSEE $(200 \mathrm{mg} / \mathrm{kg}$ ) considerably reduced the joint volume from the first day till the end of treatment as compared to arthritic control group (Fig 7). 


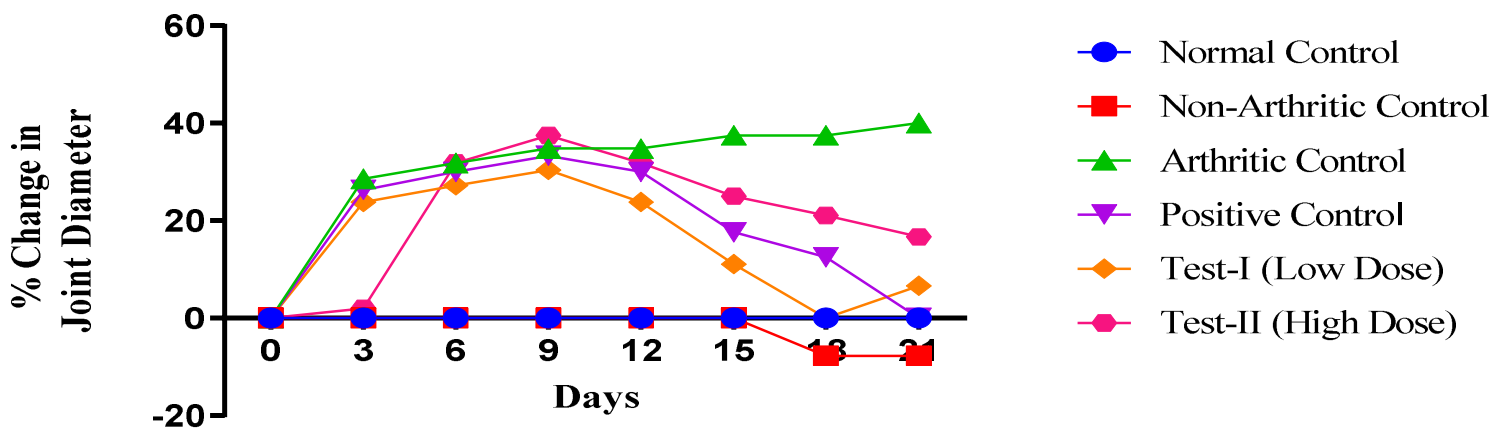

Fig 7: Effect of NESS \% change in joint diameter in CFA induced arthritic rats

Arthritic Index: In the CFA induced arthritic control group, the ipsilateral paw joints started to show swelling and rigidity from around day $8-10$ and arthritic score reached the maximum level on day 18 . All the treated groups suppressed the arthritic score significantly from day 10 to day 21 . There were significant reductions in arthritic indices for both doses (200 and $400 \mathrm{mg} / \mathrm{kg}$ ), respectively, as well as reference drug compared with the CFA-arthritic animals. The results of both doses were comparable with standard drug dexamethasone (3 mg/kg) (Fig 8).

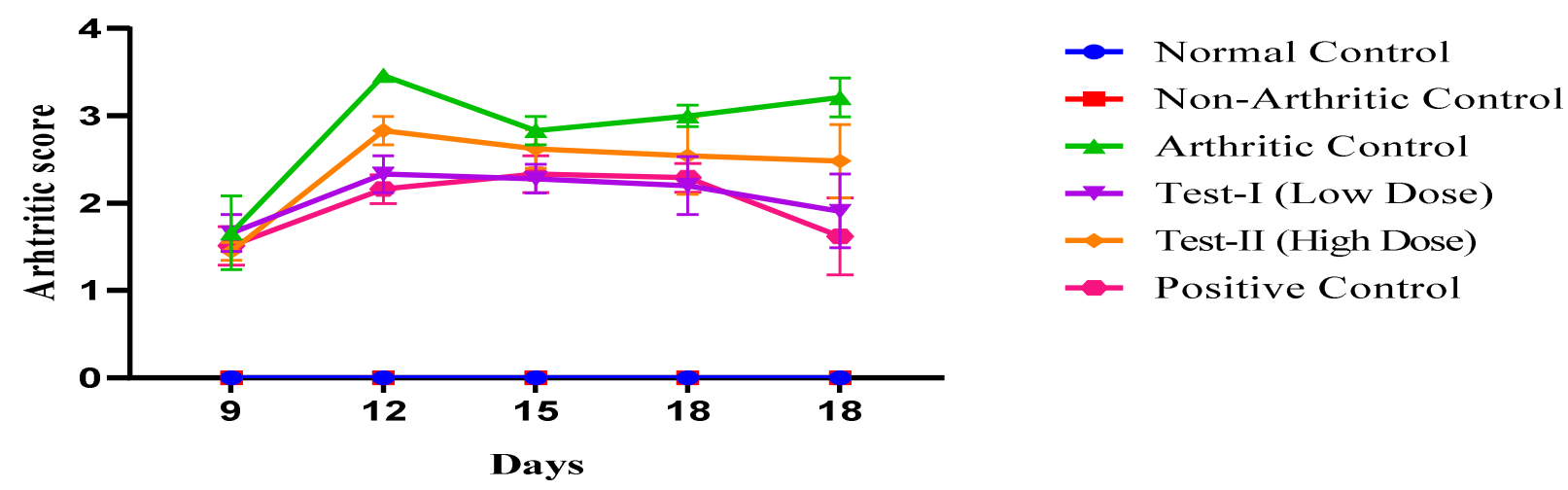

Fig 8: Effect of NESS on arthritic score in CFA induced arthritic rats

Body Weight: The animals in which arthritis has been induced gained less weight due to generation of immune responses which was lower than vehicle controls, throughout the study. The animals treated with DEX (3 mg/kg) and NSEE (200 \& $400 \mathrm{mg} / \mathrm{kg}$ ) showed significant increase in body weights of rats as compared to rats in arthritic control (Fig 9).

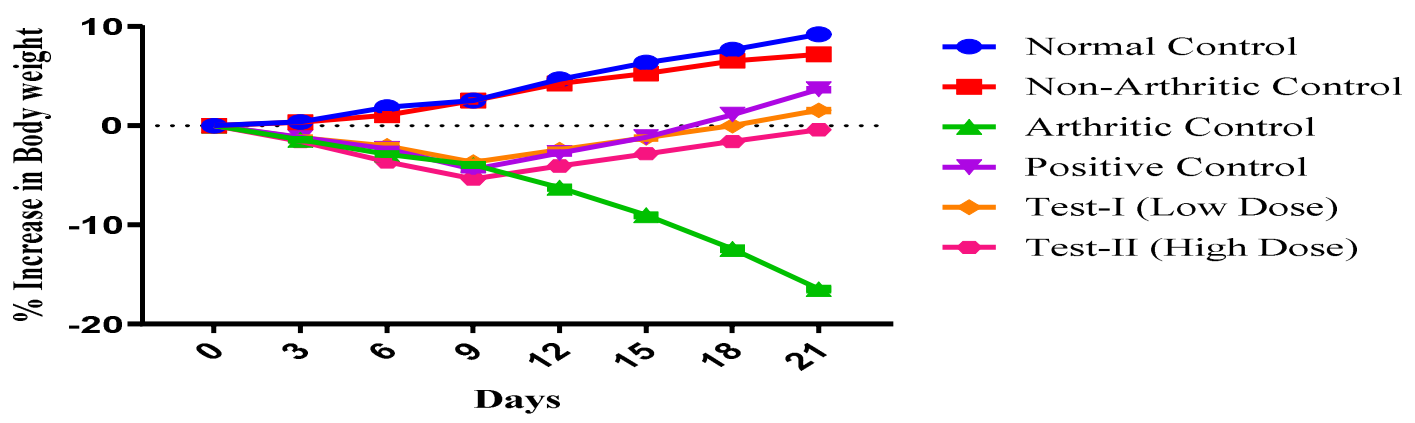

Fig 9: Effect of NESS on body weight in CFA induced arthritic rats 
Hematological Parameters: Hematological assessment indicated significant difference in red blood cells and white blood cell counts of NSEE (200 \& $400 \mathrm{mg} / \mathrm{kg})$, and dexamethasone $(3 \mathrm{mg} / \mathrm{kg})$ treated groups compared to the FCA arthritic animals. Erythrocyte sedimentation rate and WBC count was significantly low with extract and standard reference drug as compared to FCA-arthritic rats. Further hematological studies revealed significantly more hemoglobin level only in animals treated with dexamethasone $(3 \mathrm{mg} / \mathrm{kg})$. Similarly, an elevated platelet level is observed in arthritic control group as compared with control group. Treatment with extract and dexamethasone and NSEE caused significant attenuation of platelet counts as compared with arthritic control group. The results are summed up in Table 2.

Table 2: Effect of Nigella sativa on hematological parameters in CFA induced arthritic rats $(\mathrm{n}=5$, Mean \pm SEM)

\begin{tabular}{|c|c|c|c|c|c|c|}
\hline Parameters & $\begin{array}{l}\text { Normal } \\
\text { Control }\end{array}$ & $\begin{array}{c}\text { Non } \\
\text { Arthritic } \\
\text { Control } \\
\end{array}$ & $\begin{array}{l}\text { Arthritic } \\
\text { Control }\end{array}$ & $\begin{array}{l}\text { Positive } \\
\text { Control }\end{array}$ & $\begin{array}{l}\text { Test I (Low } \\
\text { dose) }\end{array}$ & $\begin{array}{c}\text { Test II } \\
\text { (High dose) }\end{array}$ \\
\hline Hemoglobin (gm \%) & $\begin{array}{l}15.9 \pm \\
0.078\end{array}$ & $\begin{array}{c}14.6 \pm \\
0.073\end{array}$ & $\begin{array}{c}10.4^{\# \# \#} \pm \\
0.052\end{array}$ & $\begin{array}{c}15.3^{* * * *} \pm \\
0.076\end{array}$ & $\begin{array}{c}13.1^{* * * *} \pm \\
0.067\end{array}$ & $\begin{array}{l}11.1^{* * * *} \\
0.056\end{array}$ \\
\hline $\begin{array}{l}\text { Total RBC Count } \\
(\mathrm{mil} / \mathrm{cmm})\end{array}$ & $\begin{array}{c}9.00 \pm \\
0.045\end{array}$ & $\begin{array}{c}8.60 \pm \\
0.043\end{array}$ & $\begin{array}{c}5.65^{\# \# \#} \pm \\
0.028\end{array}$ & $\begin{array}{c}8.72^{* * * *} \pm \\
0.044\end{array}$ & $\begin{array}{l}8.54^{* * *} \pm \\
0.043\end{array}$ & $\begin{array}{c}7.89^{* *} \pm \\
0.040\end{array}$ \\
\hline $\begin{array}{l}\text { Total Leucocyte Count } \\
\text { (cells/cmm) }\end{array}$ & $\begin{array}{c}15.43 \pm \\
0.077\end{array}$ & $\begin{array}{c}14.23 \pm \\
0.071\end{array}$ & $\begin{array}{c}22.70^{\# \# \#} \pm \\
0.114\end{array}$ & $\begin{array}{c}12.20^{* * *} \pm \\
0.061\end{array}$ & $\begin{array}{c}11.80^{* * *} \\
0.059\end{array}$ & $\begin{array}{c}10.50^{* * *} \\
0.053\end{array}$ \\
\hline Neutrophils (\%) & $29 \pm 0.145$ & $23 \pm 0.115$ & $48^{\# \#} \pm 0.24$ & $26^{* * * *} \pm$ & $\begin{array}{c}22^{* * * *} \pm \\
0.11\end{array}$ & $28^{* * *} \pm 0.14$ \\
\hline Lymphocytes (\%) & $62 \pm 0.310$ & $63 \pm 0.315$ & $\begin{array}{c}87^{\# \#} \pm \\
0.435 \\
\end{array}$ & $\begin{array}{c}60^{* * * *} \pm \\
0.300 \\
\end{array}$ & $\begin{array}{c}66^{* * *} \pm \\
0.330 \\
\end{array}$ & $69^{* *} \pm 0.345$ \\
\hline Eosinophils (\%) & $03 \pm 0.015$ & $04 \pm 0.02$ & $\begin{array}{c}06^{\# \# \# \#} \pm \\
0.03 \\
\end{array}$ & $\begin{array}{c}03^{* * *} \pm \\
0.015 \\
\end{array}$ & $\begin{array}{c}04^{* * * *} \\
0.02 \\
\end{array}$ & $\begin{array}{c}05^{* * *} \pm \\
0.025 \\
\end{array}$ \\
\hline Monocytes (\%) & $02 \pm 0.01$ & $02 \pm 0.01$ & $\begin{array}{c}05^{\# \#} \pm \\
0.025\end{array}$ & $\begin{array}{l}01^{* * * * *} \pm \\
0.005\end{array}$ & $02^{* * *} \pm 0.01$ & $\begin{array}{c}03^{* * *} \pm \\
0.015\end{array}$ \\
\hline $\begin{array}{c}\text { Erythrocyte } \\
\text { Sedimentation } \\
\text { Rate }(\mathbf{m m} / \mathrm{hr})\end{array}$ & $05 \pm 0.025$ & $06 \pm 0.030$ & $\begin{array}{c}10^{\# \# \#} \pm \\
0.050\end{array}$ & $\begin{array}{l}05^{* * *} \pm \\
0.025\end{array}$ & $\begin{array}{c}06^{* * * *} \pm \\
0.030\end{array}$ & $\begin{array}{c}07^{* * *} \pm \\
0.035\end{array}$ \\
\hline
\end{tabular}

Each value represents mean $\pm S E M, n=5$ animals in each group.

Two way ANNOVA followed by TUKEY'S, multiple comparisons test.

${ }^{\#} P<0.05,{ }^{\#} P<0.01{ }^{\# \# \#} P<0.001,{ }^{\# \# \#} P<0.0001$ when compared with normal control and $* P<0.05, * * P<0.01 * * * P$ $<0.001, * * * * P<0.0001$ when compared with arthritic control values for corresponding hematological parameters.

Biochemical parameters: The arthritic control group showed a significant increase in the serum levels of ALP, ALT, AST, RF and CRP, whereas the standard, NSEE treated groups showed marked decrease in the serum levels of ALP, ALT, AST, RF and CRP in the arthritic rats. The values obtained were found to be statistically significant. In animals treated with extract or dexamethasone, all biochemical parameters evaluated tend to return to normal values. The results are summed up in Table 3. 
Table 3: Effect of Nigella sativa on biochemical parameters in CFA induced arthritic rats $(n=5$, Mean \pm SEM)

\begin{tabular}{|c|c|c|c|c|c|c|}
\hline Parameters & $\begin{array}{l}\text { Normal } \\
\text { Control }\end{array}$ & $\begin{array}{c}\text { Non } \\
\text { Arthritic } \\
\text { Control } \\
\end{array}$ & $\begin{array}{c}\text { Arthritic } \\
\text { Control }\end{array}$ & $\begin{array}{l}\text { Positive } \\
\text { Control }\end{array}$ & $\begin{array}{l}\text { Test I } \\
\text { (Low } \\
\text { dose) }\end{array}$ & $\begin{array}{l}\text { Test II } \\
\text { (High } \\
\text { dose) }\end{array}$ \\
\hline SGOT (U/L) & $26 \pm 0.13$ & $28 \pm 0.14$ & $\begin{array}{c}39^{\# \#} \pm \\
0.195\end{array}$ & $\begin{array}{c}29^{* * * *} \pm \\
0.145\end{array}$ & $\begin{array}{c}30^{* * * *} \pm \\
0.15\end{array}$ & $\begin{array}{c}34^{* * * *} \pm \\
0.17\end{array}$ \\
\hline SGPT (U/L) & $38 \pm 0.19$ & $40 \pm 0.2$ & $\begin{array}{c}47^{\# \# \#} \pm \\
0.235\end{array}$ & $\begin{array}{c}34^{* * * *} \pm \\
0.17\end{array}$ & $\begin{array}{c}38^{* * * *} \pm \\
0.19\end{array}$ & $40^{* * *} \pm 0.2$ \\
\hline $\operatorname{ALP}(I U / L)$ & $68 \pm 0.34$ & $87 \pm 0.435$ & $\begin{array}{c}148^{\# \#} \pm \\
0.74\end{array}$ & $\begin{array}{c}78^{* * * *} \pm \\
0.39\end{array}$ & $\begin{array}{c}81^{* * * *} \pm \\
0.405\end{array}$ & $\begin{array}{c}89^{* * * *} \pm \\
0.445\end{array}$ \\
\hline $\begin{array}{c}\text { Rheumatoid } \\
\text { Factor } \\
\text { (IU/mL) }\end{array}$ & $8 \pm 0.04$ & $8 \pm 0.04$ & $12^{\# \# \#} \pm 0.06$ & $8^{* * * *} \pm 0.04$ & $10^{* * * *} \pm$ & $\begin{array}{c}12^{* * *} \pm \\
0.06\end{array}$ \\
\hline $\begin{array}{c}\text { C-Reactive } \\
\text { Protein(mg/L) }\end{array}$ & $4 \pm 0.02$ & $15 \pm 0.025$ & $24^{\# \# \#} \pm 0.12$ & $4^{* * * *} \pm 0.02$ & $4^{* * *} \pm 0.02$ & $6^{* * *} \pm 0.03$ \\
\hline
\end{tabular}

Each value represents mean $\pm \mathrm{SEM}, \mathrm{n}=5$ animals in each group.

Two way ANNOVA followed by TUKEY'S, multiple comparisons test.

${ }^{\#} P<0.05,{ }^{\# \#} P<0.01{ }^{\# \# \#} P<0.001,{ }^{\# \# \#} P<0.0001$ when compared with normal control and $* P<0.05,{ }^{* *} P<0.01{ }^{* * *} P$ $<0.001,{ }^{* * * *} P<0.0001$ when compared with arthritic control values for corresponding biochemical parameters.

Histopathological studies: The histopathological studies showed differences in the normal ankle joint and adjuvant-induced arthritic rat joint. In the CFA treated animals, hisotopathological slides showed very disturbed synovial architecture, large joint space, cells infiltration, vascularization and bone erosion. Dexamethasone treatment showed normal

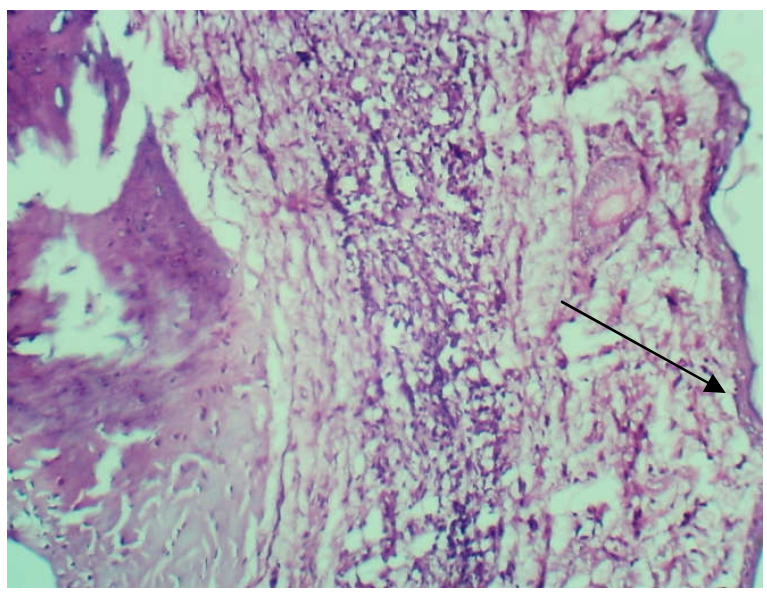

$\boldsymbol{A}$ thin epidermis and intact synovial architecture. The rats treated with NSEE produced ankle joint protection when compared to arthritic rats. The animals treated with $200 \mathrm{mg} / \mathrm{kg}$ showed decreased vascularization and bone erosion whereas animals treated with $400 \mathrm{mg} / \mathrm{kg}$ showed partial effect and appears as bone and synovial lining are regenerating.

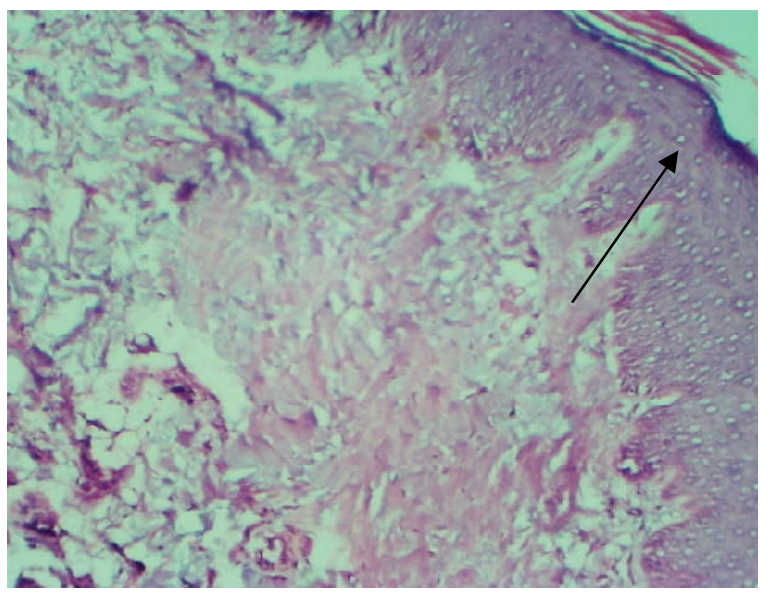

B 


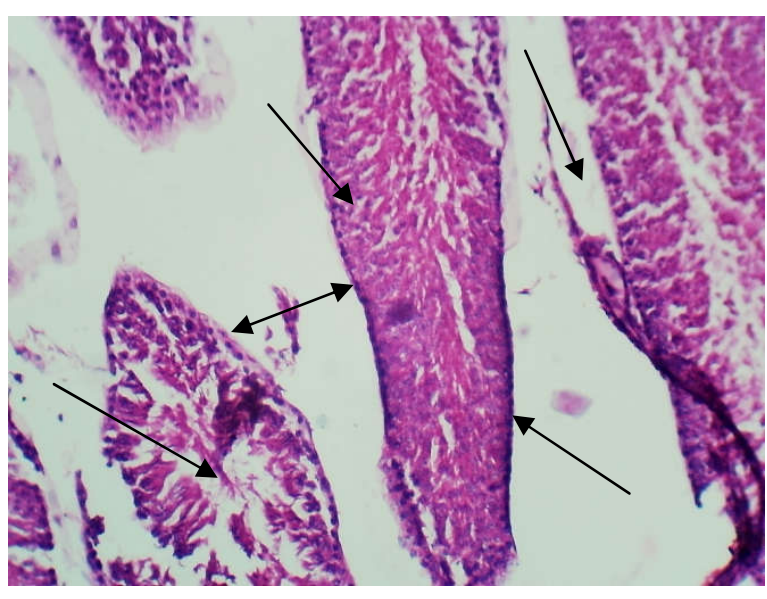

C

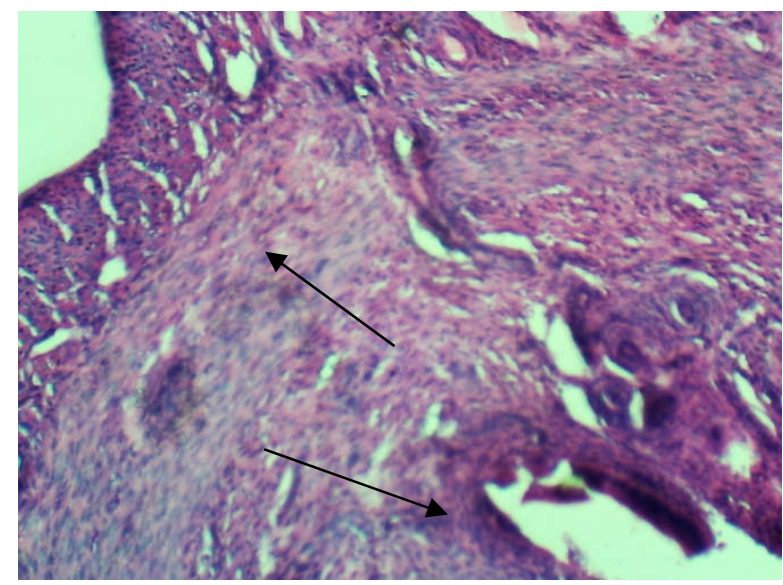

$\boldsymbol{E}$

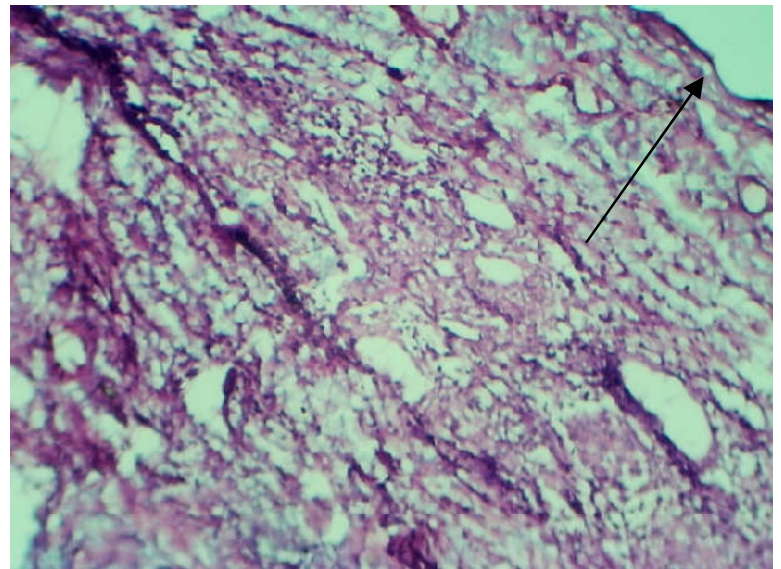

D

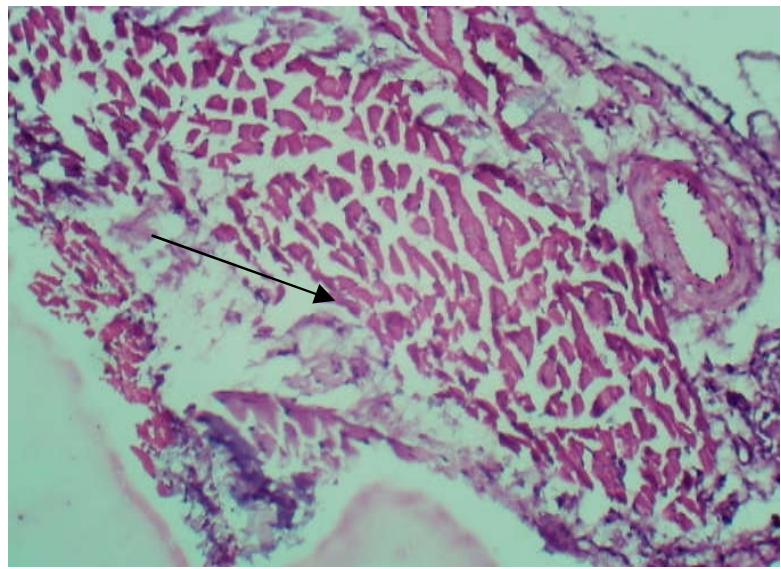

$\boldsymbol{F}$

A \& B: Normal and Non-arthritic control showed intact synovial architecture. C: Arthritic control shows very disturbed synovial architecture, large joint space, cells infiltration, vascularization and bone erosion. D: Dexamethasone treated group shows response in the form of normal thin epidermis and intact synovial architecture. E: NSEE $(200 \mathrm{mg} / \mathrm{kg})$ showed decreased vascularization and bone erosion. F: NSEE $(400 \mathrm{mg} / \mathrm{kg})$ showed partial effect of drug and appears as bone and synovial lining are regenerating.

\section{Fig 10: Histopathology of Bone tissue}

\section{DISCUSSION}

Various animal models are used in the preclinical research in inflammatory arthritis. Freund's complete adjuvant induced arthritis is well established rat model which have been extensively used in the evaluation of anti-arthritic potential of various agents in preclinical research. The present study investigated the vitro and vivo anti- arthritic activity of ethanolic extract of Nigella sativa. The major findings of this study included inhibition of protein (albumin) denaturation, inhibition of paw and joint edema and suppression of certain arthritic parameters.

Protein denaturation is a process in which proteins lose their tertiary structure and secondary structure due to extrinsic stress, heat, organic solvent or strong acid or base. The mechanism of denaturation comprises variation in electrostatic, hydrogen, hydrophobic and disulphide bonding. In the present investigation, the increments in absorbance of test sample with respect to control indicated that Nigella sativa has 
capability to bring down thermal denaturation of protein (albumin).

Changes in the paw volume of the adjuvant-induced arthritic rats were measured using digital plethysmometer. From the results obtained, it was observed that NSEE $200 \mathrm{mg} / \mathrm{kg}$ was effective in equivalent to the standard drug Dexamethasone on reducing the increase in paw volume, whereas NSEE $400 \mathrm{mg} / \mathrm{kg}$ showed moderate effect on prevention of paw oedema compared to the arthritic control group. The development of FCA induced arthritis in the rat can be characterized by pronounced swelling in the hind paw primary chronic arthritis. In primary reaction, prostaglandin generations occur, which is followed by swelling in contralateral and ipsilateral paws (secondary chronic arthritis) in which autoantibodies are generated. A good antiarthritic agent should be able to suppress one or both of these phases. Recent studies have shown the role of various proinflammatory mediators such as tumour necrosis factor $(\mathrm{TNF}-\alpha)$, interleukin-1 beta (IL-1 $\beta)$, and platelet derived growth factor (PDGF) in the pathogenesis of RA.

Anemia is commonly noted in patients with chronic arthritis. The two most common explanations are gastrointestinal blood loss due to arthritis medications and bonemarrow changes in patients with inflammatory arthritis, which prevents the release of iron for incorporation into red blood cells. In CFA induced arthritis model, arthritic control rats showed reduced $\mathrm{RBC}$ and $\mathrm{WBC}$ count, reduced $\mathrm{Hb}$ count, and increased erythrocyte sedimentation rate (ESR) and RF levels. It is proposed that the reduction in the $\mathrm{Hb}$ count during arthritis results from reduced erythropoietin levels, a decreased response of the bone marrow erythropoietin, and premature destruction of red blood cells. Similarly, an increase in the ESR is attributed to the accelerated formation of endogenous proteins such as fibrinogen and $\alpha / \beta$ globulin, and such a rise in the ESR indicates an active but obscure disease process. The acute phase proteins in ESR share the property of showing elevations in the concentration in response to stress or inflammations like injection, injury, surgery,and tissue necrosis.

Plasma cells produce antibodies (e.g., IgM) that contribute to these complexes. Serum RF measures the amount of antibody IgM titre present in the serum. RF is the immunological expression of an individual's immune system reaction to the presence of an immunoglobulin molecule that is recognized as nonself. This response to the nonself immunoglobulin results in the presence of immune complexes; these in turn bind to the complement and may eventually lead to destruction of synovium, cartilage, and bone. The higher the levels of serum RF, higher the development of inflammation. Determination of serum RF levels in rheumatoid arthritis is essential to understand and measure the disease progression and to facilitate the development of novel treatments for rheumatoid arthritis.

The assessment of the serum levels of ALP, ALT, AST and CRP is a tool to measure the antiarthritic activity of a particular drug. AST and ALT plays a vital role in the formation of biologically active chemical mediators such as bradykinins in the inflammatory process. The elevated levels of ALP in the adjuvant-induced arthritic rats may be due to the increase in the liver and bone fraction. This leads to localized bone loss in the form of bone erosion and periarticular osteopenia, as the enzyme is released into circulation in the course of bone formation and resorption. CRP is a prototypic inflammatory biomarker of systemic inflammation which belongs to the class of acute phase proteins. The level of CRP increases during the inflammatory process that occurs in the body and the increase in the level of CRP is due to the rise in the plasma concentration of IL-6, which is produced by the macrophages and the adipocytes.

Histopathological study shows the differences in the normal ankle joint and adjuvantinduced arthritic rat joint. In general, histopathological studies on arthritic joint shows the prominent abnormalities from the normal joint like oedema formation, degeneration with partial erosion of the cartilage, destruction of bone marrow and extensive infiltration of inflammatory exudates in the articular surface. In the present study, the histopathological studies of hind paw joints in arthritic control rats showed the prominent abnormalities like destruction of the bone marrow and extensive infiltration of the cells in the articular surface. NSEE $(200 \mathrm{mg} / \mathrm{kg})$ treatment have shown marked reduction in all the above mentioned pathological conditions, indicating its effective antiarthritic activity by protecting the bone from degeneration.

\section{CONCLUSION}

The results of the present study suggest that the ethonolic extract of Nigella sativa seeds have good anti-arthritic potential. It demonstrates the beneficial effect during recovery from arthritis by improving haematinic properties and body weight along with clinical signs including paw 
edema, joint diameter and histopathological examination. The effect may be due to the inhibition of phospholipase A2 and prostaglandins similar to the effect of dexamethasone. The anti-arthritic effect ethanolic extract of $N$. sativa, established in this study could be attributed to the presence of flavonoids, triterpenoid, saponins, tannins and steroids detected after phytochemical screening. The study predicts that the $N$. sativa provides pharmacological rationale for the traditional use of the plant against inflammation disorders like rheumatoid arthritis. However, further studies are needed to identify and isolate the possible phytoconstituents involved in the anti arthritic activity, which would facilitate the use of $N$. sativa in inflammatory disease.

\section{REFERENCES}

1. Arthritis Foundation, about arthritis. Accessed from www.arthritis.org/aboutarthritis/types/rheumatoid-arthritis/what-isrheumatoid-arthritis.php.

2. Abdurohaman Mengesha Yessuf, Phytochemical Extraction and Screening of Bio Active Compounds from Black Cumin (Nigella sativa) Seeds Extract, American Journal of Life Sciences, 2015; 3 (5): 358 364.

3. K. Nivetha, G. Prasanna, GC-MS and FT-IR Analysis of Nigella sativa L. Seeds, International Journal of Advanced Research in Biological Sciences, 2016; 3 (6): 45 - 54.

4. Ebrahim M. Yimer, Kald Beshir Tuem, Aman Karim, Najeeb Ur-Rehman, Farooq Anwar, Nigella sativa L. (Black Cumin): A Promising Natural Remedy for Wide Range of Illnesses, Evidence-Based Complementary and Alternative Medicine, 2019; 1 - 16.

5. B. H. Ali, Gerald Blunden, Pharmacological and Toxicological Properties of Nigella sativa, Phytotheapy Research, 2003; 17: 299 - 305.

6. Ahmad Fahmi Harun Ismail, Abd Almonem Doolaanea, Farahidah Mohamed, Nur 'Izzati Mansor, Mohd Affendi Mohd Shafri, Fathin Athirah Yusof, Method Development and ValidationusingUVSpectrophotometryfor
Nigella sativa oil Microparticles Quantification, Journal of Applied Pharmaceutical Science, Sep 2015; 5 (09): $82-88$.

7. M. Khader, N. Bresgen, P.M. Eckl, In vitro toxicological properties of thymoquinone, Food and Chemical Toxicology, 2009; 47, 129-133.

8. Shaheen baya, Bioweb, University of Wisconsin-La Crosse, Nigella sativa; the blessed seed. Accessed from bioweb.uwlax.edu/bio203/s2009/shaheen_ba ya/index.

9. Devender Sharma, Kajal V. Kosankar, Ameya M. Lanjewar, Extraction and Chemical Tests on Nigella sativa $L$. Collected from Vidarbha Region of India, World Journal of Pharmaceutical Research, 2018; 7 (02): 532 - 540.

10. Alamgeer, Ambreen Malik Uttra, Umme Habiba Hasan, Anti-arthritic activity of aqueous-methanolic extract and various fractions of Berberis orthobotrys Bien ex Aitch, BMC Complementary and Alternative Medicine, 2017; 17: 371 - 386.

11. Inemesit Okon Ben, Eric Woode, George Asumeng Koffuor, Eric Boakye-Gyasi, Nicholas Akinwale Titiloye, Effect of Trichilia monadelpha (Meliaceae) extracts on bone histomorphology in complete Freund's adjuvant-induced arthritis, Journal of Intercultural Ethnopharmacology, 2017; 6 (2), $177-185$.

12. Manjusha Choudhary, Vipin Kumar, Pankaj Gupta, and Surender Singh, Investigation of Antiarthritic Potential of Plumeria alba L. Leaves in Acute and Chronic Models of Arthritis, BioMed Research International, 2014; 1 - 12 .

13. Ajay D. Kshirsagar, Prashant V. Panchal, Uday N. Harle, Rabindra K. Nanda, Haidarali M. Shaikh, Anti-Inflammatory and Antiarthritic Activity of Anthraquinone Derivatives in Rodents International Journal of Inflammation, 2014, 1 - 12. 